\title{
Erratum to: Complicated confessionality: How the concept of 'confessionality' could serve the debate on religious education better?
}

\section{Jacoleena Kimanen ${ }^{1}$}

Published online: 14 November 2016

(c) Australian Catholic University 2016

Erratum to: j. relig. educ. DOI 10.1007/s40839-016-0023-3

The author given name is Jacoleena and not Annuleena as given in the article.

The online version of the original article can be found under doi:10.1007/s40839-016-0023-3.

$\triangle$ Jacoleena Kimanen

anuleena.kimanen@helsinki.fi

1 Department of Teacher Education, University of Helsinki, Espoo, Finland 